\title{
Hubungan Indeks Massa Tubuh dengan Ketahanan Kardiorespirasi, Kekuatan dan Ketahanan Otot dan Fleksibilitas pada Mahasiswa Laki-Laki Jurusan Pendidikan Dokter Universitas Andalas Angkatan 2013
}

\author{
Haslan Muhaimin Lubis ${ }^{1}$, Delmi Sulastri ${ }^{2}$, Afriwardi $^{3}$
}

\begin{abstract}
Abstrak
Komponen kebugaran jasmani yang berhubungan dengan kesahatan adalah ketahanan kardiorespirasi, komposisi tubuh yang dinilai dengan Indek Massa Tubuh (IMT), kekuatan dan ketahanan otot dan fleksibilitas. Kebugaran jasmani bersifat individual. Tujuan penelitian ini adalah untuk mengetahui hubungan antara IMT dengan ketahanan kardiorespirasi, kekuatan dan ketahanan otot, dan fleksibilitas. Penelitian dilakukan pada mahasiswa Fakultas Kedokteran Universitas Andalas Padang pada bulan Nopember - Desember 2013. Penelitian ini merupakan studi observasional analitik menggunakan desain cross sectional study dengan jumlah 72 orang. Ketahanan kardiorespirasi didapat dengan menghitung nilai $\mathrm{VO}_{2}$ maks menggunakan tes ergometer sepeda metode Astrand 6 minute cycle test. Dilakukan pengukuran berat badan dan tinggi badan. Kekuatan otot dinilai dengan hand dynamometer dan back strength dynamometer, ketahanan otot dinilai dengan bent leg sit-up dan fleksibilitas dinilai dengan sit and reach test, trunk extension, dan shoulder lift. Hasil pengukuran rerata IMT 22,08 $\pm 4,55, \mathrm{VO}_{2} \mathrm{maks}$ $35,27 \pm 2,25$, grip strength kanan $32,44 \pm 7,04$, grip strength kiri $30,31 \pm 7,2$, back strength $100,9 \pm 19,43$, bent leg situp 29,29 $\pm 8,43$ dalam 1 menit, sit and reach test 4,61 $\pm 2,61$, trunk extension 29,21 $\pm 10,01$, dan shoulder lift 38,06 \pm 9,5 .
\end{abstract}

Kata kunci: $\mathrm{BMI}, \mathrm{VO}_{2}$ maks, IMT, kekuatan dan ketahanan otot, fleksibilitas

\begin{abstract}
The component of physical fitness which related to health are cardiorespiratory endurance, body composition (Body Mass Index/BMI), muscle strength and endurance, and flexibility. The objective of this research was to determine the relationship between BMI with cardiorespiratory endurance, muscle strength and endurance, and flexibility. This research has been done on male students of Medical Faculty of Andalas University on November January 2013. This was a study observational analitic using design cross sectional study by the number of 72 people. Cardiorespiratory endurance obtained by calculating the value of bycycle ergometer test using VO2maks method astrand 6 minute cycle test, conducted measurement of height and weight, muscle strength is graded with a hand dynamometer and back strength dynamometer, muscle endurance is assessed with the bent leg sit-up, and flexibility with the sit and reach test, trunk extension, and shoulder lift. Data were analyzed by using SPSS. The result showed average body mass index 22,08 \pm 4,55, VO2 max 35,27 $\pm 2,25$, right grip strength $32,44 \pm 7,04$, left grip strength 30,31 $\pm 7,2$, back strength $100,9 \pm 19,43$, bent leg sit-up $29,29 \pm 8,43$ in one minute, sit and reach test 4,61 $\pm 2,61$, trunk extension $29,21 \pm 10,01$, and shoulder lift 38,06 $\pm 9,5$.
\end{abstract}

Keywords: $\mathrm{BMI}, \mathrm{VO}_{2}$ maks, muscle strength and endurance, flexibility.

Affiliasi penulis : 1. Pendidikan Dokter FK UNAND (Fakultas

Kedokteran Universitas Andalas Padang), 2. Bagian IImu Gizi FK

UNAND, 3. Bagian Fisiologi FK UNAND
Korespondensi :Haslan Muhaimin Lubis, E-mail :

haslanmuhaiminlubis@yahoo.co.id,Telp: 081376467435 


\section{PENDAHULUAN}

Semua bentuk kegiatan manusia selalu memerlukan dukungan fisik atau jasmani sehingga masalah kemampuan fisik atau jasmani menjadi faktor dasar bagi aktivitas manusia. Oleh karena itu, untuk aktivitas sehari-hari, minimal harus mempunyai kemampuan fisik atau jasmani yang selalu mendukung tuntutan aktivitas rutin itu dan tentu saja lebih baik lagi apabila memiliki cadangannya. Adanya kemampuan fisik yang melebihi kebutuhan minimal, menjamin kelancaran tugas dan kesejahteraan karena masih dapat melakukan tugas tambahan setelah melakukan aktivitas rutin, ini dikenal dengan istilah kebugaran jasmani. ${ }^{1}$

Kebugaran sangat diperlukan untuk menghadapi persaingan yang ketat di era globalisasi ini. Persaingan tersebut menuntut tubuh dalam kondisi prima dan bugar, tidak cukup hanya sebatas keadaan fisik yang sehat saja. ${ }^{2}$ Seseorang yang merasa sehat belum tentu bugar karena untuk dapat mengerjakan pekerjaan sehari-hari, seseorang tidak hanya dituntut bebas dari penyakit saja tetapi juga dituntut memiliki kebugaran jasmani. ${ }^{3}$ Kebugaran jasmani yaitu kemampuan seseorang dalam melakukan kegiatan sehari-hari secara efisian tanpa menimbulkan kelelahan yang berlebihan sehingga masih dapat menjalankan aktivitas lain diluar aktivitas rutin tersebut. Kebugaran jasmani terdiri atas dua komponen, yaitu kebugaran yang berhubungan dengan kesehatan dan kebugaran yang berhubungan dengan kemampuan olahraga. Kebugaran jasmani yang berhubungan dengan kesehatan terdiri atas ketahanan kardiorespirasi, komposisi tubuh, kekuatan dan ketahanan otot dan fleksibilitas sedangkan kebugaran jasmani yang berhubungan dengan kemampuan olahraga terdiri atas ketangkasan, keseimbangan, koordinasi, kecepatan, kekuatan dan waktu reaksi. Ketahanan kardiorespirasi dapat dijadikan pedoman langsung dalam menentukan tingkat kebugaran jasmani karena kemampuan ambilan oksigen saat melakukan latihan fisik mencerminkan kemampuan metabolisme yang dimiliki seseorang. Ketahanan kardiorespirasi adalah kapasitas maksimal untuk menghirup, menyalurkan, dan menggunakan oksigen. Seseorang yang memiliki daya tahan paru-jantung baik, tidak akan cepat kelelahan setelah melakukan serangkaian aktivitas. Kualitas daya tahan jantung-paru dinyatakan dalam $\mathrm{VO}_{2}$ max, yaitu banyaknya oksigen maksimal yang dapat dikonsumsi maksimal dalam satuan $\mathrm{ml} / \mathrm{KgBB} /$ menit. Kekuatan otot adalah kemampuan sekelompok otot melawan beban dalam satu usaha dan ketahanan otot adalah kemampuan sekelompok otot melakukan serangkaian kerja dalam waktu yang lama. $^{2-5}$ Fleksibilitas dikenal juga dengan istilah kelenturan yaitu ketersediaan ruang gerak sendi dalam memberikan toleransi terhadap upaya penggunaan sendi secara maksimal. Tiap-tiap komponen kebugaran jasmani yang berhubungan dengan kesehatan dapat dinilai terpisah. Seseorang yang memiliki ketahanan kardiorespirasi baik belum tentu memiliki kekuatan dan ketahanan otot serta fleksibilitas yang baik juga, begitu juga sebaliknya. ${ }^{2,4}$ Kebugaran jasmani bersifat individualistik, artinya setiap orang akan berbeda kebugaran jasmaninya tergantung pada kegiatan fisik rutin yang dilakukannya. $^{2}$

Pada mahasiswa kebugaran jasmani sangat penting dalam mendukung, mempermudah, dan memperlancar aktivitas perkuliahannya. ${ }^{6}$ Mahasiswa merupakan orang yang belajar di perguruan tinggi yang berada pada kisaran umur dewasa awal, yaitu sekitar 19-28 tahun yang merupakan usia peralihan dari remaja menjadi dewasa. Seorang mahasiswa dikenal dengan sikap kedinamisannya dan keilmuannya dalam melihat sesuatu berdasarkan kenyataan objektif, sistematis, dan rasional. $^{7}$ Penelitian di Fakultas IImu Keolahragaan (FIK) UNY didapatkan 12,72 mahasiswa angkatan 2009 memiliki tingkat kebugaran jasmani sangat buruk, 20\% buruk, $40 \%$ sedang, $14,55 \%$ baik, dan $12,72 \%$ sangat baik. Artinya, dari 55 sampel yang diteliti hanya 27,27\% yang memiliki tingkat kebugaran jasmani baik. Bahkan, penelitian di fakultas kedokteran Universitas Andalas pada tahun 2007 terhadap 100 orang mahasiswa angkatan 2003-2006 didapatkan 56\% memiliki tingkat kebugaran jasmani kurang, 44\% memiliki tingkat kategori sedang, dan $0 \%$ yang memiliki tingkat kebugaran jasmani baik. Penelitian di DKI Jakarta dan Jawa Barat pada karyawan didapatkan 92,4\% karyawan memiliki kebugaran parujantung dengan kategori kurang dan kurang sekali, 
$17 \%$ mamiliki kekuatan otot kategori kurang dan 5\% memiliki kelenturan otot kategori kurang. ${ }^{3} \mathrm{Di}$ Indonesia, hasil pengukuran tingkat kebugaran jasmani di 22 provinsi yang dilakukan oleh pusat kesegaran jasmani pada tahun 2005 terhadap 7685 orang sampel didapatkan $34,4 \%$ memilki tingkat kebugaran jasmani kurang dan kurang sekali, 9,53\% memiliki tingkat kebugaran jasmani baik dan baik sekali, dan sisanya dinyatakan sedang. ${ }^{8}$ Banyak faktor yang mempengaruhi tingkat kebugaran jasmani seseorang, diantaranya usia, jenis kelamin, keturunan atau hereditas, makanan, kebiasaan merokok, latihan, aktivitas fisik dan lemak tubuh. ${ }^{2}$ Akumulasi lemak dapat menurunkan kebugaran fisik. ${ }^{7}$ Penelitian pada karyawan di Jawa Barat dan DKI Jakarta didapatkan $24 \%$ memiliki lemak tubuh yang berlebih. ${ }^{3}$

Jaringan lemak merupakan jaringan yang tidak terlibat langsung dalam proses pembentukan energi. Yang terlibat langsung dalam pembentukan energi adalah jaringan otot. Orang yang gemuk memilki jaringan lemak yang lebih banyak daripada jaringan otot sehingga memiliki kemampuan yang kecil dalam menghasilkan energi. Kebugaran jasmani akan lebih baik pada seseorang yang memiliki lebih banyak jaringan aktif dibandingkan seseorang yang sedikit memiliki jaringan aktif. ${ }^{2}$

Sejak tahun 1985, batasan berat badan normal orang dewasa dinilai berdasarkan Body Mass Index (BMI). BMI diterjemahkan menjadi Indeks Massa Tubuh (IMT). IMT merupakan pengukuran sederhana dalam menentukan status gizi seseorang. IMT tersebut terbagi atas tiga golongan, yaitu kurus, normal, dan gemuk. ${ }^{9}$ Secara klinis IMT yang bernilai $25-29,9 \mathrm{~kg} / \mathrm{m}^{2}$ disebut overweight dan nilai IMT lebih dari $30 \mathrm{~kg} / \mathrm{m}^{2}$ disebut obese. ${ }^{10}$ Penelitian di Fakultas IImu Keolahragaan (FIK) UNY didapatkan 78,18\% dari 55 sampel mahasiswa yang diteliti memiliki IMT normal, tetapi hanya $22,27 \%$ yang memiliki tingkat kebugaran jasmani yang baik. ${ }^{6}$ Penelitian di Fakultas Kedokteran USU pada tahun 2011 terhadap mahasiswa angkatan 2010 didapatkan 32,7\% dari 49 sampel mengalami obesitas dan $14,3 \%$ memiliki tingkat kebugaran kurang bahkan 10,2\% memiliki tingkat kebugaran yang sangat kurang. ${ }^{11}$

Berdasarkan hal diatas, perlu dilakukan penelitian tentang hubungan IMT dengan ketahanan kardiorespirasi, kekuatan dan ketahanan otot, dan fleksibilitas pada mahasiswa laki-laki jurusan Pendidikan Dokter Fakultas Kedokteran Universitas Andalas angkatan 2013.

\section{METODE}

Jenis penelitian ini adalah studi analitik dengan desain cross sectional. Populasi penelitian adalah mahasiswa Pendidikan Dokter Unand angkatan 2013. Subjek didapat berjumlah 80 orang yang diambil berdasarkan metode simple random sampling. Kriteria inklusi sampel adalah mahasiswa Pendidikan Dokter Unand angkatan 2013, berjenis kelamin pria, berusia 17-25 tahun, sehat jasmani, bersedia mengikuti penelitian dan menandatangani surat persetujuan. Kriteria ekslusi antara lain memiliki riwayat penyakit sistem kardiovaskular, riwayat penyakit paru, sedang mengonsumsi obat penurun berat badan atau obat penambah hormon, perokok berat, mengalami cedera pada kaki, dan olahragawan. Penelitian dilaksanakan dari bulan November 2013 sampai Januari 2014.

Variabel dependen penelitian adalah IMT yang dinyatakan dengan $\mathrm{kg} / \mathrm{m}^{2}$. Alat yang digunakan untuk menimbang berat badan adalah timbangan injak merk Smic dengan ketelitian $0,1 \mathrm{~kg}$ dan untuk mengukur tinggi badan menggunakan microtoise dengan ketelitian $0,1 \mathrm{~cm}$. Hasil pengukuran dikategorikan menjadi kurus jika IMT $<17$ atau IMT 17-18,5, normal jika IMT 18,7-25, gemuk jika IMT > 25-27 atau lebih dari 27. Variabel independen adalah ketahanan kardiorespirasi, kekuatan dan ketahanan otot dan fleksibilitas. Daya tahan kardiorespirasi adalah kesanggupan sistem jantung, paru dan pembuluh darah untuk berfungsi secara optimal pada keadaan istirahat dan kerja dalam mengambil oksigen dan menyalurkan ke jaringan yang aktif sehingga dapat digunakan pada proses metabolisme tubuh. Data didapatkan dengan cara tes ergometer sepeda dengan hasil $\mathrm{VO}_{2}$ maks ( $\mathrm{mlO} 2 / \mathrm{kg} /$ menit). Kekuatan otot adalah kemampuan sekelompok otot melawan beban dalam satu usaha. Data didapat dengan cara ukur menggunakan Alat Dynamometer dengan hasil ukur berupa persentil. Ketahanan otot adalah kemampuan sekelompok otot melakukan serangkaian kerja dalam waktu yang lama. Data didapat dengan menggunakan 
Bent-Leg Sit Up dan hasil ukurnya berupa persentil. Fleksibilitas atau Kelenturan adalah ketersediaan ruang gerak sendi dalam memberikan toleransi terhadap upaya penggunaan sendi secara maksimal. Data didapat dengan cara ukurSit and Reach Test, Trunk Extension, Shoulder Lift. Hasil ukur berupa Persentil.

Tahap pengolahan data yang dilakukan yaitu memeriksa kelengkapan data, memberikan kode pada setiap data yang telah terkumpul, memasukkan data ke dalam komputer dan memeriksa kembali data yang telah dimasukkan untuk memastikan data tersebut telah bersih dari kesalahan. Analisis data terdiri dari analisis univariat dan bivariat. Analisis bivariat digunakan untuk mengetahui hubungan antara dua variabel yaitu IMT dengan ketahanan kardiorespirasi, kekuatan dan ketahanan otot, dan fleksibilitas menggunakan uji Chi Square dengan derajat kemaknaan $p<0,05$. Data yang telah didapat diuji normalitasnya secara komputerisasi dengan Kolmogorov-Smirnov. Selanjutnya dilakukan uji korelasi Spearman pada data tidak normal dan uji korelasi Pearson pada data normal.

\section{HASIL}

Dari 80 subjek penelitian didapatkan 72 orang yang memenuhi kriteria inklusi.
Tabel 1. Distribusi Frekuensi Indeks Massa Tubuh, Volume Oksigen Maksimal, Hand Dynamometer, Back Strength Dynamometer, Bent leg sit-up, Sit and reach test, Trunk Extension, dan Shoulder Lift Responden Penelitian

\begin{tabular}{|c|c|c|}
\hline Variabel & Jumlah (n = 72) & $\%$ \\
\hline IMT & $22,08 \pm 4,55^{1}$ & \\
\hline Kurus & 17 & 23,6 \\
\hline Normal & 41 & 56,9 \\
\hline Gemuk & 14 & 19,4 \\
\hline $\mathrm{VO}_{2}$ maks & $35,00(28-46)^{2}$ & \\
\hline Buruk & 66 & 91,7 \\
\hline Sedang & 5 & 6,9 \\
\hline Baik & 1 & 1,4 \\
\hline Grip Strength Kanan & $32,44 \pm 7,04^{1}$ & \\
\hline$<15$ & 1 & 1,4 \\
\hline $15-30$ & 22 & 30,6 \\
\hline$>30$ & 49 & 68,1 \\
\hline Grip Strength Kiri & $30,31 \pm 7,2^{1}$ & \\
\hline$<15$ & 1 & 1,4 \\
\hline $15-30$ & 29 & 40,3 \\
\hline$>30$ & 42 & 58,3 \\
\hline Back Strength & $100,9 \pm 19,43^{1}$ & \\
\hline$<50$ & 0 & 0 \\
\hline $50-100$ & 30 & 41,7 \\
\hline$>100$ & 42 & 58,3 \\
\hline Bent Leg Sit-up & $29,29 \pm 8,43^{1}$ & \\
\hline Buruk & 58 & 80,6 \\
\hline Sedang & 2 & 2,8 \\
\hline Baik & 12 & 16,7 \\
\hline Sit and Reach Test & $4,61 \pm 2,61^{1}$ & \\
\hline Buruk & 21 & 29,2 \\
\hline Sedang & 0 & 0 \\
\hline Baik & 51 & 70,8 \\
\hline Trunk Extension & $29,21 \pm 10,01^{1}$ & \\
\hline Buruk & 9 & 12,5 \\
\hline Sedang & 2 & 2,8 \\
\hline Baik & 61 & 84,7 \\
\hline Shoulder Lift & $38,06 \pm 9,5^{1}$ & \\
\hline Buruk & 0 & 0 \\
\hline Sedang & 2 & 2,8 \\
\hline Baik & 70 & 97,2 \\
\hline
\end{tabular}

${ }^{1}$ Data disajikan dalam bentuk mean \pm standar deviasi ${ }^{2}$ Data disajikan dalam bentuk median (minimummaksimum)

IMT= Indeks Massa Tubuh

VO2maks $=$ Volume Oksigen Maksimal 
Tabel 2. Korelasi IMT dengan Ketahanan Kardiorespirasi, Grip Strength Kanan, Grip Strength Kiri, Ketahanan Otot, Back Strength, Sit and Reach Test, Trunk Extension, dan Shoulder lift

\begin{tabular}{lcc}
\hline \multicolumn{1}{c}{ Variabel } & \multicolumn{2}{c}{ IMT } \\
\cline { 2 - 3 } & $\mathrm{R}$ & $\mathrm{P}$ \\
\hline $\mathrm{VO}_{2}$ maks & $-0,302$ & $0,010^{* 1}$ \\
Grip Strength Kanan & 0,128 & $0,283^{2}$ \\
Grip Strength Kiri & 0,151 & $0,204^{2}$ \\
Back Strength & 0,411 & $0,000{ }^{* 2}$ \\
Ketahanan Otot & $-0,283$ & $0,016^{* 2}$ \\
Sit and Reach Test & $-0,303$ & $0,010^{* 2}$ \\
Trunk Extension & $-0,017$ & $0,890^{2}$ \\
Shoulder Lift & 0,061 & $0,613^{2}$ \\
\hline Keterangan : & & \\
${ }^{1}$ Diuji dengan Spearmen-Rank & & \\
${ }^{2}$ Diuji dengan korelasi pearson & & \\
$\mathrm{r}=$ koefisien korelasi & & \\
$\mathrm{P}=$ batas kemaknaan < 0,05 & & \\
${ }^{*}=$ bermakna
\end{tabular}

\section{PEMBAHASAN}

\section{Indeks Massa Tubuh}

Hasil pengukuran rata-rata indeks massa tubuh responden 22,08 \pm 4,55 (15 - 37). Berdasarkan nilai rerata IMT tersebut, dapat dikatakan bahwa IMT mahasiswa laki-laki FK Unand angkatan 2013 masuk dalam kategori normal. Jumlah responden yang normal 41 orang (56,9\%).

Hal ini sejalan dengan penelitian yang dilakukan oleh Peter Pribis dkk yang dilakukan terhadap 5101 mahasiswa pada Universitas Andrews di Amerika, dimana didapatkan rata-rata IMT responden normal yaitu $24,1 \pm 4,5 .{ }^{12}$ Selain itu, penelitian oleh Dewi Permaesih dkk juga didapatkan rata-rata IMT dari 234 responden yang diteliti adalah normal yaitu 23,66 $\pm 2,36(18,91-30,86) .{ }^{13}$ Penelitian oleh Baskaran C dkk kepada 229 mahasiswa didapatkan rata-rata IMT responden normal yaitu $22,99 \pm 2,65(16,80-29,41) .^{14}$

\section{Ketahanan Kardiorespirasi}

Hasil pengukuran median volume oksigen maksimal responden $35,00 \mathrm{mlO}_{2}{ }^{\prime} \mathrm{kg}^{\prime}$ menit (28 - 46 $\mathrm{mlO}_{2} / \mathrm{kg} /$ menit). Artinya, pada umumnya responden memiliki ketahanan kardiorespirasi yang buruk yaitu 66 orang (91,7\%). Ketahanan kardiorespirasi $\left(\mathrm{VO}_{2}\right.$ maks) dapat menggambarkan kebugaran jasmani seseorang. Faktor-faktor yang mempengaruhi kebugaran aerobik adalah hereditas, latihan, jenis kelamin, usia, lemak tubuh dan aktivitas. ${ }^{5}$

Hal ini sesuai dengan penelitian Wahyu A didapatkan rerata ketahanan kardiorespirasi pada responden laki-laki sangat buruk yaitu 25,6 sebelum intervensi dan 30,15 setelah intervensi. Selain itu penelitian oleh Y. Rosmalina dkk dengan metode lari sejauh 2,4 km didapatkan rerata ketahanan kardiorespirasi responden di kota yang diteliti yaitu $18,54 \pm 2,63$ dan responden di desa $14,44 \pm 1,79 .^{15}$

\section{Kekuatan dan Ketahanan Otot}

Hasil pengukuran rerata grip strength kanan $32,44 \pm 7,04$ (12 - 48), grip strength kiri 30,31 \pm 7,2 (10 - 53), dan hasil pengukuran rata-rata back strength 100,9 $\pm 19,43(56-140)$.

Hasil pengukuran rerata bent leg sit-up 29,29 $\pm 8,43$ dalam 1 menit (13 - $52 \times$ dalam 1 menit). Sebagian besar responden mahasiswa memiliki ketahanan otot buruk yaitu 58 orang (80,6\%). Kekuatan otot adalah suatu kemampuan untuk menghasilkan tenaga. ${ }^{16}$

Daya tahan otot mencerminkan kemampuan dalam hal bertahan melaksanakan suatu aktivitas. Seseorang telah memiliki tenaga untuk melakukan aktivitas yang berulang-ulang, peningkatan performa akan bergantung pada daya tahan otot. ${ }^{5}$

Penelitian oleh Y.Rosmalina dkk didapatkan rerata kekuatan otot tangan kanan pada responden di kota adalah 24,95 tangan kiri 23,11 dan rerata kekuatan otot tangan kanan pada responden di desa adalah 23,24 dan tangan kiri 21,42. ${ }^{15}$ Hasil yang hampir sama terdapat pada penelitian W. Ambartana dimana rerata kekuatan genggam tangan kanan 33,6, genggam tangan kiri 31,2, dan otot punggung 66,9. ${ }^{17}$ Penelitian oleh Samad E dkk pada tahun 2012 terhadap 766 responden berumur antara $7-11$ tahun didapatkan rata-rata grip strength responden adalah 18,3 $\pm 5,6 .^{18}$ Pada penelitian Y.Rosmalina dkk didapatkan rerata ketahanan otot dari responden yang diteliti rendah yaitu rerata sit-up dalam 30 detik pada responden di kota adalah 15,08 dan rerata sit-up responden di desa adalah $13,22 .{ }^{15}$ Penelitian oleh Agustini didapatkan rerata ketahanan otot responden yang diperiksa dengan sit up juga rendah yaitu $14,7 \times$ 
dalam 30 detik. $^{16}$ Penelitian oleh Samad $\mathrm{E}$ et al terhadap 766 responden berumur antara $7-11$ tahun didapatkan rerata sit up dalam 1 menit buruk yaitu $19,0 \pm 10,8 .^{18}$

\section{Fleksibilitas}

Hasil pengukuran rerata sit and reach test 4,61 $\pm 2,61$ (-3 - 9), trunk extension 29,21 \pm 10,01 (5 50), dan shoulder lift 38,06 $\pm 9,5$ (20 - 72). Berdasarkan profil fleksibilitas laki-laki sebagian besar responden mahasiswa memiliki kelenturan sit and reach test, trunk extension, dan shoulder lift yang baik yaitu 51 orang (70,8\%) fleksibilitas sit and reach test, 61 orang $(84,7 \%)$ fleksibilitas trunk extension, dan 70 orang $(97,2 \%)$ fleksibilitas shoulder lift baik.

Fleksibilitas yang baik memberikan kontribusi pada pekerjaan dan aktivitas olahraga. Latihan fleksibilitas sangat penting untuk mempertahankan fleksibilitas yang dapat berkurang. ${ }^{5}$

Penelitian oleh Rosmalina dkk didapatkan rerata fleksibilitas dengan jangkauan tangan pada responden di kota adalah 20,52 $\mathrm{cm}$ dan di desa 19,47 $\mathrm{cm}^{15}$ Penelitian oleh Kristine AM dkk didapatkan rerata sit and reach test baik yaitu 30 inci dimana kategori baik yaitu sit and reach test $25-36$ inci. $^{19}$

\section{Korelasi Indeks Massa Tubuh dengan Ketahahan Kardiorespirasi}

Dari tabel 2 didapatkan nilai $r=-0,302$ dan $p$ $=0,010$ lebih kecil dari 0,05 yang berarti terdapat korelasi negatif yang bermakna antara IMT dengan $\mathrm{VO}_{2}$ maks dengan tingkat korelasi lemah. Nilai $\mathrm{R}^{2}=$ 0,0912 artinya nilai prediksinya sebesar $9,12 \%$ artinya IMT mampu menerangkan atau memprediksi nilai $\mathrm{VO}_{2}$ maks sebesar $6,15 \%$ sisanya sebesar $93,85 \%$ nilai $\mathrm{VO}_{2}$ maks diterangkan oleh faktor lain selain IMT.

Faktor-faktor lain yang mempengaruhi ketahanan kardiorespirasi adalah hereditas, latihan, jenis kelamin, usia, lemak tubuh, dan aktivitas fisik. Aktivitas fisik adalah hal yang paling mempengaruhi tingkat kebugaran seseorang. Aktivitas yang dilakukan hari demi hari akan membentuk kesehatan, vitalitas, dan kualitas hidup. Pengaruh latihan bertahun-tahun dapat hilang hanya dalam 12 minggu dengan menghentikan aktivitas. Latihan aerobik tidak mengubah ukuran paru-paru, tetapi dapat meningkatkan kondisi dan efisiensi otot pernapasan sehingga memungkinkan penggunaan kapasitas yang lebih besar. ${ }^{5}$ Penelitian pada tahun 2007, didapatkan bahwa responden yang melakukan olahraga memiliki tingkat kebugaran jasmani dengan kategori cukup lebih banyak daripada responden yang tidak berolahraga. $^{20}$

Presentase lemak tubuh yang berlebih merugikan kesehatan karena berisiko menderita penyakit degeneratif. ${ }^{3}$ Obesitas didefinisikan dengan IMT yang lebih besar dari $25 \mathrm{~kg} / \mathrm{m}^{2}{ }^{4}$ Penelitian yang dilakukan Peter $\mathrm{P}$ dkk didapatkan korelasi negatif yang bermakna antara IMT dengan $\mathrm{VO}_{2}$ maks dengan $r=$ 0,334 dan $p<0,001 .^{12}$ Penelitian oleh Dewi $P$ didapatkan korelasi negatif yang bermakna antara IMT dengan ketahanan kardiorespirasi dengan $r=-0,45$ dan $p=0,000$. Dari penelitian tersebut menunjukkan bahwa semakin tinggi IMT semakin rendah tingkat ketahanan kardiorespirasinya. Jumlah timbunan lemak berkorelasi dengan tingkat ketahanan kardiorespirasi. ${ }^{13}$ Penelitian oleh Wi-Young So dkk didapatkan penurunan yang signifikan tingkat $\mathrm{VO}_{2}$ maks pada responden yang obesitas yaitu rerata $\mathrm{VO}_{2}$ maks responden normal adalah $37,26 \pm 6,32$, overweight $33,08 \pm 5,53$ dan obesitas $31,37 \pm 6,21$ denga nilai $p=<0,001$. $^{21}$

\section{Korelasi Indeks Masa Tubuh dengan Kekuatan dan Ketahanan Otot}

Dari tabel 2 didapatkan nilai $r=0,128$ dan $p=$ 0,283 lebih besar dari 0,05 yang berarti tidak terdapat korelasi yang bermakna antara IMT dengan grip strength kanan. Nilai $R^{2}=0,016$ artinya nilai prediksinya sebesar $1,6 \%$ yang dapat memperkirakan nilai kekuatan otot tangan kanan melalui IMT. Hal ini tidak berbeda jauh dengan penilaian pada tangan kiri dimana dari tabel 2 nilai $r=0,151$ dan $p=0,204$ lebih besar dari 0,05 yang berarti tidak terdapat korelasi yang bermakna antara IMT dengan grip strength kiri. Nilai $R^{2}=0,023$ artinya nilai prediksinya sebesar $2,3 \%$ yang dapat menjelaskan pengaruh IMT terhadap kekuatan otot tangan kiri.

Hal yang berbanding terbalik didapatkan pada pengukuran kekuatan otot punggung, dimana pada tabel 2 nilai $r=0,411$ dan $p=0,000$ lebih kecil dari 0,05 yang berarti terdapat korelasi positif yang 
bermakna antara IMT dengan back strength dengan tingkat korelasi sedang. Nilai $R^{2}=0,169$ artinya nilai prediksinya sebesar $16,9 \%$ yang dapat memperkirakan nilai kekuatan otot punggung melalui IMT.

Penelitian Ambartana pada responden yang diteliti didapatkan rerata kekuatan genggam tangan kanan 30,7 pada IMT <18,5, 34,6 pada IMT 18,5-25, dan 38,8 pada IMT >25, kekuatan genggam tangan kiri 28,6 pada IMT $<18,5$, 32,3 pada IMT 18,5-25, dan 34,8 pada IMT >25, dan kekuatan otot punggung 61,3 pada IMT <18,5, 68,6 pada IMT 18,5-25, dan 76,7 pada IMT >25 yang menggambarkan terjadi peningkatan kekuatan otot setiap peningkatan IMT. Selain itu, pada penelitian yang sama juga tidak didapatkan korelasi antara IMT dengan kekuatan otot tangan kanan dengan nilai $p=0,3719$ dan kekuatan tangan kiri dengan nilai $p=0,3153 .{ }^{17}$ Penelitian Rebecca Hardy et al didapatkan pada responden lakilaki yang memiliki IMT yang lebih tinggi akan memiliki grip strength yang lebih kuat. Didapatkan grip strength akan makin meningkat $0,22 \mathrm{~kg}$ setiap penambahan IMT $1 \mathrm{~kg} / \mathrm{m}^{2}{ }^{22}$

Pada tabel 2 didapatkan nilai $r=-0,283$ dan $p$ $=0,016$ lebih kecil dari 0,05 yang berarti terdapat korelasi negatif yang bermakna antara IMT dengan ketahanan otot dengan tingkat korelasi lemah. Nilai $\mathrm{R}^{2}$ $=0,08$ artinya nilai prediksinya sebesar $8 \%$ yang dapat memperkirakan nilai ketahanan otot terhadap IMT.

Penelitian oleh Agustini $U$ didapatkan hubungan yang signifikan antara IMT dengan ketahanan otot dengan nilai $p=0,000$ dan nilai $r=$ 0,751 . Dimana setiap peningkatan IMT $1 \mathrm{~kg} / \mathrm{m} 2$ akan terjadi penurunan ketahanan otot sebesar $0,751 .^{16}$ Penetian oleh Samad E didapatkan perbedaan yang signifikan rata-rata jumlah sit up responden dengan berbagai IMT, pada IMT underweight 20,2 \pm 11 , normal 19,0 \pm 10,8, overweight 17,3 \pm 10,5, dan obesitas $12,8 \pm 9,5$ dengan nilai $p<0,05 .{ }^{18}$ Penelitian oleh Wi-Young So et al didapatkan penurunan yang signifikan tingkat ketahanan otot responder berdasarkan tingkat IMT, pada responden dengan IMT normal rerata ketahanan otot $25,13 \pm 5,98$, overweight $24,57 \pm 6,41$, dan obesitas $23,43 \pm 7,58$. $^{21}$

\section{Korelasi Indeks Masa Tubuh dengan Fleksibilitas}

Dari tabel 2 nilai $r=-0,303$ dan $p=0,010$ lebih kecil dari 0,05 yang berarti terdapat korelasi negatif yang bermakna antara IMT dengan sit and reach test dengan tingkat korelasi lemah. Nilai $\mathrm{R}^{2}=$ 0,092 artinya nilai prediksinya sebesar $9,2 \%$ yang dapat memperkirakan kekuatan IMT terhadap sit and reach test. Berbeda dengan trunk extension dan shoulder lift, pada trunk extension yang dapat dilihat pada tabel 2 nilai $r=0,017$ dan $p=0,890$ lebih besar dari 0,05 yang berarti tidak terdapat korelasi yang bermakna antara IMT dengan trunk extension. Nilai $R^{2}=0,000$ artinya nilai prediksinya sebesar $0 \%$ yang dapat memperkirakan kekuatan IMT terhadap trunk extension dan pada shoulder lift yang dapat dilihat pada tabel 2 nilai $r=0,061$ dan $p=0,613$ lebih besar dari 0,05 yang berarti tidak terdapat korelasi yang bermakna antara IMT dengan shoulder lift. Nilai $R^{2}=0,004$ artinya nilai prediksinya sebesar $0,4 \%$ yang dapat memperkirakan kekuatan IMT terhadap shoulder lift.

Penelitian dalam Journal of Student Research didapatkan hubungan antara IMT dengan trunk extension dengan $p=0,04 .^{23}$ Pada penelitian oleh Samad E didapatkan korelasi yang bermakna antara IMT dengan sit and reach test dengan nilai $p<$ $0,05 .^{18}$

\section{KESIMPULAN}

Terdapat korelasi negatif yang lemah antara indeks massa tubuh dengan ketahanan kardiorespirasi. Tidak terdapat korelasi antara indeks massa tubuh dengan kekuatan otot tangan, tetapi terdapat korelasi positif yang sedang antara indeks massa tubuh dengan kekuatan otot punggung. Terdapat korelasi yang lemah antara indeks massa tubuh dengan ketahanan otot. Terdapat korelasi lift yang lemah antara indeks massa tubuh dengan sit and reach test tetapi tidak terdapat korelasi antara indeks massa tubuh dengan trunk extension dan shoulder. 


\section{UCAPAN TERIMAKASIH}

Ucapan terima kasih kepada Prof. DR. dr. Delmi Sulastri, MS, Sp.GK dan DR. dr. Afriwardi, Sp.KO, MA atas bimbingan, bantuan dan motivasi dalam penelitian ini.

\section{DAFTAR PUSTAKA}

1. Firdaus K. Fisiologi olahraga dan aplikasinya. Fakultas IImu Keolahragaan Universitas Negeri Padang Press. Padang; 2011.

2. Afriwardi. IImu kedokteran olahraga. Jakarta: EGC; 2010

3. Irianto JP. Pedoman praktis berolahraga untuk kebugaran dan kesehatan. Yogyakarta: Penerbit Andi Offset; 2004.

4. Nieman DC. Kebugaran dan Kesehatan Anda, alih bahasa Syahrastani, M.Kes. Padang: Universitas Negeri Padang; 2004.

5. Sharkey JB. Kebugaran dan kesehatan. Edisi ke1. Jakarta: Penerbit Raja Grafindo Persada; 2003

6. Swasta EB. Kebugaran jasmani dan indeks massa tubuh mahasiswa program studi IKORA FIK UNY. 2010 (diunduh 28 Mei 2013). Tersedia dari: URL: HYPERLINK http://staff.uny.ac.id/ sites/default/files/Artikel\%20Majalah\%281\%29.

7. Aladawiyyah R. Analisis hubungan antara kecukupan gizi dan status gizi dengan tingkat kebugaran mahasiswa IPB. 2012 (diunduh 28 Mei 2013). Tersedia dari: URL: HYPERLINK http://repository.ipb.ac.id/handle/123456789/5624 5.

8. Susilowati. Faktor-faktor risiko yang berpengaruh terhadap kesegaran jasmani polisi lalu lintas di kota Semarang. 2007 (diunduh 28 Mei 2013). Tersedia dari: URL: HYPERLINK http://eprints. undip.ac.id/5268/1/Susilowati.pdf

9. Supariasa IDN, Bachyar B, Ibnu F. Penilaian status gizi. Jakarta: EGC; 2002.

10. Guyton AC, Hall JE. Buku ajar fisiologi kedokteran. Edisi ke-11. (Diterjemahkan oleh: Irawati et al). Jakarta: EGC: 2008.

11. Olivia W. Hubungan indeks massa tubuh dengan kebugaran fisik pada mahasiswa laki-laki fakultas kedokteran Universitas Sumatera Utara Tahun Masuk 2010. 2011 (diunduh 27 Mei 2013). Tersedia dari: URL: HYPERLINK http://repository.usu.ac.id/handle/123456789/314 $\underline{63}$

12. Pribis $P$, et al. Trends in body fat, body mass index, and physical fitness among male and female college students. 2010 (diunduh 12 Januari 2014). Tersedia dari: URL: HYPERLINK http://www.ncbi.nlm.nih.govpmcarticlesPMC3257 619pdfnutrients-02-01075.pdf

13. Permaesih D, et al. Faktor-faktor yang mempengaruhi ketahanan kardiovaskuler pada pria dewasa. 2000 (diunduh 12 Januari 2014). Tersedia dari: URL: HYPERLINK http://ejournal. litbang.depkes.go.idindex.phpBPKarticleview306 $\underline{346}$

14. Chandrasekaran B, et al. Age and antropometric traits predict handgrip strength in healthy normals. 2010 (diunduh 12 Januari 2014). Tersedia dari: URL: HYPERLINK http://www.ncbi. nlm.nih.govpmcarticlesPMC3122705pdf12593 2 010 Article 15.pdf

15. Rosmalina $Y$, et al. Tingkat Kesegaran Jasmani dan Aktivitas Fisik Murid SMP Non-Anemia yang Tinggal di Kota dan di Desa. 2010 (diunduh 22 Desember 2013). Tersedia dari: URL: HYPERLINK http://ejournal.litbang.depkes.go. idindex.phppgmarticleview31183083

16. Utari A. Hubungan indeks massa tubuh dengan tingkat kesegaran jasmani pada anak usia 12-14 tahun. 2007 (diunduh 28 Mei 2013). Tersedia dari: URL: HYPERLINK http://eprints.undip.ac.id/ 16285/1/AGUSTINI UTARI.pdf

17. Ambartana W. Hubungan status gizi dengan kekuatan otot lanjut usia di kelurahan Gianyar Kabupaten Gianyar Provinsi Bali. 2010 (diunduh 22 Desember 2013). Tersedia dari: URL: HYPERLINK http://poltekkes-denpasar.ac.idfiles JIGV1N1ambartana.pdf

18. Esmaeilzade S, Ebadollahzadeh K. Physical fitness, physical activity and sedentary activities of 7 to 11 years old boys with different body mass indexes. 2012 (diunduh 12 Januari 2014). Tersedia dari: URL: HYPERLINK http://www.ncbi. nlm.nih.govpmcarticlesPMC3426729pdfASJSM3-105.pdf

19. Madsen KA, Linchey J. School - based BMI and Body Composition Screening and Parent 
Notification in California : methods and messages. 2013 (diunduh 12 Januari 2014). Tersedia dari: URL: HYPERLINK http://www.ncbi. nlm.nih.govpmcarticlesPMC3349433pdfnihms36 3385.pdf.

20. Kampar P. Hubungan aktivitas fisik dengan tingkat kebugaran jasmani pada mahasiswa angkatan tahun 2003-2006. Padang: Fakultas Kedokteran Universitas Andalas; 2007.

21. So W, Choi D. Differences in physical fitness and cardiovascular function depend on BMI in Korean Men. 2010 (diunduh 12 Januari 2014). Tersedia dari: URL: HYPERLINK http://www.ncbi. nlm.nih.
govpmcarticlesPMC3761729pdfjssm-09-239.pdf

22. Hardy, Rebecca, et al. Body mass index, muscle strength and physical performance in older adults from eigth cohort studies: The HALCyon Programme. 2013 (diunduh 22 Desember 2013). Tersedia dari: URL: HYEPERLINK http://www. ncbi.nlm.nih.govpmcarticlesPMC3577921pdfpon e.0056483.pdf

23. Ward T. Exploring The Relationship between trunk adiposity and trunk flexibility. 2013 (diunduh 22 Desember 2013). Tersedia dari: URL: HYPERLINK http://www.jofsr.comindex. phppatharticleview13264 